\title{
Baseline Studies on Water and Sediments in the Copper Mining Region of Salobo-3A, Carajas - Amazon, Brazil
}

\author{
Nina R. Damous ${ }^{b}$, Angela de L. R. Wagener ${ }^{* a}$, Sambasiva R. Patchineelam ${ }^{c}$ and Klaus Wagener $^{a}$ \\ ${ }^{a}$ Departamento de Química, Pontifícia Universidade Católica do Rio de Janeiro, 22453-900 Rio de Janeiro - RJ, Brazil \\ ${ }^{b}$ Departamento de Geoquímica, Universidade do Pará, 66060-670 Belém - PA, Brazil \\ ${ }^{c}$ Departamento de Geoquímica, Universidade Federal Fluminense, 24020-007 Niterói - RJ, Brazil
}

\begin{abstract}
Realizou-se um estudo ambiental no sistema hidrológico da região do Salobo 3A, localizada no Distrito Mineral de Carajás, com o objetivo de obter dados sobre a química das águas, sobre a distribuição de concentração e especiação do cobre e de avaliar os primeiros impactos derivados de atividades antrópicas. As medições incluíram um número de parâmetros considerados essenciais à caracterização das matrizes. Encontrou-se que a concentração natural de cobre nas águas do Salobo estão próximas de 50-60 nmol L-1 , enquanto nas vizinhanças do complexo de mineração os valores encontrados ultrapassam $300 \mathrm{nmol} \mathrm{L}^{-1}$. As concentrações de cobre nos sedimentos encontraram-se na faixa de 61 a $1,744 \mu \mathrm{g} \mathrm{g}^{-1}$. Além de efeitos sobre a concentração total, as atividades piloto de mineração também alteraram a distribuição do cobre, entre particulado e solução, e a sua especiação nesta fase. De modo geral, as concentrações de solutos principais estão abaixo da média mundial registrada para os rios.
\end{abstract}

A survey was performed in the hydrological system of the Salobo 3A region, in the Carajás Mining Province, to obtain baseline data on the water chemistry, on the copper concentration and copper speciation, and to evaluate the first environmental impacts derived from anthropogenic activities. Measurements included copper concentration and speciation and a number of essential parameters to characterize water and sediment matrices. The natural background $\mathrm{Cu}$ concentration in Salobo waters is around $50-60 \mathrm{nmol} \mathrm{L}^{-1}$ while in the vicinities of the mining complex it reaches more than $300 \mathrm{nmol} \mathrm{L}^{-1}$. In sediments, concentrations ranged between 61 to $1.744 \mu \mathrm{g} \mathrm{g}^{-1}$. The mining activities at pilot scale resulted in substantial change in the copper distribution between particulate and dissolved phases, as well as in the dissolved copper speciation. Concentration of major water components is low compared to North America and world river average.

Keywords: Amazon region, Carajás mining Province, copper, speciation

\section{Introduction}

The Carajás complex located in Southeastern Amazon region comprises one of the largest mineral reserves in the world. There, among other activities that include iron and gold mining, a metallurgic project is under implementation to extract and upgrade copper from sulfide ore. About $1.2 \times 10^{9}$ tonne of copper are present in three deposits extending over an area of 25,000 ha limited at one side by the Salobo river, a water course of about $20 \mathrm{~km}$ long. The Mineral Province of Carajás is characterized by an eastwest oriented mountain chain reaching a maximum altitude

\footnotetext{
* e-mail: angela@rdc.puc-rio.br
}

of $800 \mathrm{~m}$. The equatorial forest cover is quasi-continuous with a large number of creepers, trees of medium height and a few dominant specimens like Bertholletia excelsa. ${ }^{1,2}$ The climate is warm tropical to mildly dry with temperatures ranging from 19 to $35{ }^{\circ} \mathrm{C}$. There are two distinct seasons: a wet season from November to May, when $90 \%$ of the total rainfall occurs $(2,116 \mathrm{~mm}$ on average), and a well-defined dry season extending from July to October. ${ }^{2}$

In the Salobo area, a $60 \mathrm{~m}$ deep altered surface rock containing copper in high concentrations (0.3-1.2 \%) bound to goethite, limonite, mica and clays, overlays the main reservoir of copper sulfides. ${ }^{3}$ The soil mineralogy is dominated by quartz, kaolinite, plagioclases, amphiboles, biotite, montmorinollites, chlorites and K-feldspar. ${ }^{4,5}$ The 
sulfide ore is primarily associated with sedimentary shale rich in iron, gold and silver, and minerals of molybdenum and cobalt. ${ }^{6}$ The copper upgrading process in the metallurgic complex includes grinding to $37 \mu \mathrm{m}$, floatation with xanthate and the addition of foaming and depressor agents. ${ }^{2}$ The efficiency of this process as well as the waste disposal procedure were tested in a pilot plant that operated in 1986 and 1987 processing 80 metric tonne of copper ore per day.

The drainage from the Copper-Carajas Project area occurs principally through the Salobo and Cinzento rivers, which are tributaries to the Itacaiunas that, in turn discharges into the Tocantins River. This hydrological network is characterized by steep slopes and by the torrential character of the rivers..$^{1,2}$ The Itacaiunas, a major river of 80 to $400 \mathrm{~m}$ wide, runs $400 \mathrm{~km}$ through the Carajás Mountains. ${ }^{2}$

Except for the Amazon and Negro rivers and some of their major affluents ${ }^{7-19}$ little is known about the chemistry of waters in the Brazilian Amazon region. Konhauser et $a l .{ }^{15}$ report a multi-elemental analysis of waters from several Amazonian rivers including the Salobo river, however, the results, in many instances given as smaller than a limit value, cannot be used to support an environmental evaluation.
Due to the magnitude of the water cycle in this region it can be expected that the chemical cycles, the transport of materials and reactivity of possible contaminants will be in great part determined by hydrological conditions. In the case of Carajás, the small-scale operation of the Copper Project over a short period provided a unique opportunity to obtain base line data on the chemistry and reactivity of copper in the neighboring rivers and forecast possible impacts under large-scale operation planned for the near future.

In the present work we discuss the results of a copper survey and speciation in waters and sediments from the Carajás River under the influence of the mining and upgrading activities.

\section{Experimental}

\section{Sampling procedure}

We performed two samplings at several stations (see Figure 1) in the rivers Salobo, Cinzento, Itacaiunas, and in the Igarapés Pojuca, Águas Claras and Prospecto Bahia (not included in Figure 1; located southeast of Itacaiunas). The first sampling was performed in November 1989 just prior to the beginning of the wet season and the second in

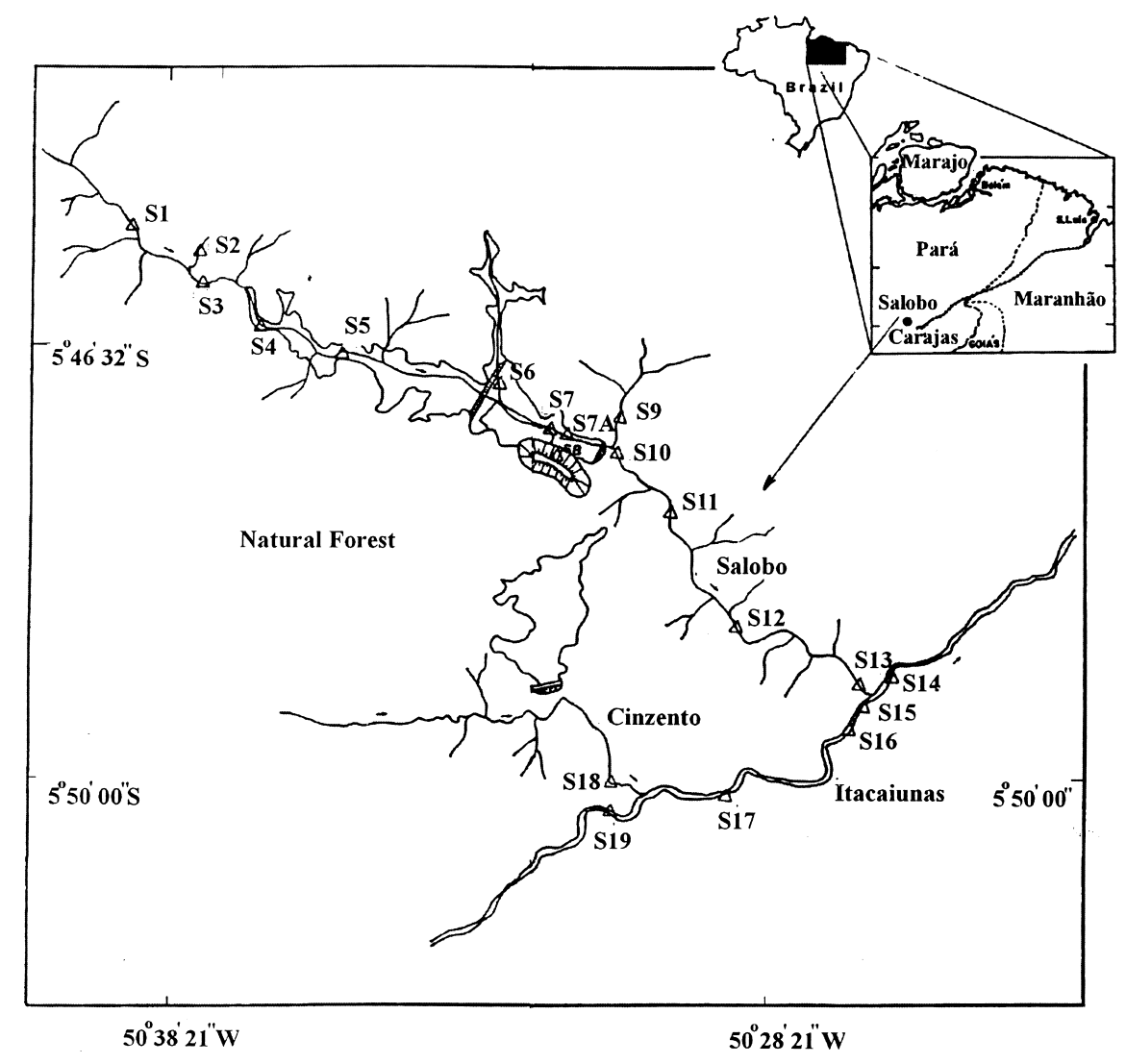

Figure 1 
June 1991 at the end of the wet period. In the second sampling the number of stations decreased from 20 to 11 due to access and transportation difficulties. In each sampling river water, sediments, ground water, exploration gallery waters (station 8), solid waste and copper ore were sampled.

Station 1 is at a site considered as the source of the Salobo Rriver. The main river course, however, is formed by the input of several small streams all the way down to station 6. Upstream station 6 a dam has been constructed for provision of water. Station 8 (not shown in Figure 1) is not directly on the river but at a stream draining from an exploration gallery in the vicinity of the pilot plant. Station 7A receives input from station 8 , and station 9 is in the Igarape Mirim, a small river entering the Salobo. Stations 14 to 17 and 19 are in the Itacaiunas River and station 18 is in the Cinzento River downstream the waste disposal site.

Waters were sampled with the help of a fishing rod ( $\sim 3 \mathrm{~m}$ long) with $1 \mathrm{~L}$ polyethylene bottles attached to the end of an acrylic support which also maintained the bottle closed when submerged. Samples were collected from the riverbank, avoiding re-suspension of bed particles, or from a motorboat. The waters were immediately filtered and processed for speciation as explained below and thereafter stored frozen in the sampling bottles enclosed in polyethylene bags.

At each sampling station, water velocity and depth and the river width were measured as basis for estimating flow rates.

Sediments were collected using either a $10 \mathrm{~cm}$ diameter PVC tube, in deeper sites, or a polyethylene shovel. We took sediments preferably from low energy sites and mixed several samples collected at 2-3 m distance from each other at each station. Samples from the first $15 \mathrm{~cm}$ of sediments were stored in clean polyethylene bags at $4{ }^{\circ} \mathrm{C}$ or frozen at $-20{ }^{\circ} \mathrm{C}$ depending on the analytical objective.

\section{Analytical procedures: waters}

Water aliquots were filtered through $0.4 \mathrm{~mm}$ Nuclepore filters, $0.45 \mu \mathrm{m}$ Millipore filters and $0.7 \mathrm{~mm}$ fiber glass filters for determination of particulate copper, suspended matter and particulate organic matter (POM), respectively. The Millipore filtrates were used for determination of $\mathrm{Ca}$, $\mathrm{Mg}, \mathrm{Na}, \mathrm{K}, \mathrm{Cl}^{-}, \mathrm{NO}_{3}{ }^{-}, \mathrm{PO}_{4}{ }^{3-}$ and $\mathrm{SO}_{4}{ }^{2-}$. In the particulate matter $\mathrm{Al}, \mathrm{Fe}$ and $\mathrm{Mn}$ were determined after treatment with $\mathrm{HNO}_{3}, \mathrm{H}_{2} \mathrm{O}_{2}$ and $\mathrm{HF}$ in Teflon digestion bombs. ${ }^{20}$ For the analysis of cations we used Flame Atomic Absorption (Perkin Elmer 1100) and for anion determinations, Ion Chromatography (Dionex 4500 1). Dissolved copper was determined in the Nuclepore filtrate as described below, and dissolved organic and inorganic carbon in the fiberglass filtrate using a TOC Beckman Analyzer 915B. POC was determined using a LECO CS-244 instrument. Temperature and $\mathrm{pH}$ were measured in situ.

The procedure for $\mathrm{Cu}$ speciation was based on that described in Nürnberg, ${ }^{21}$ and Zhou and Wangersky. ${ }^{22}$ Copper in unfiltered water samples was determined by DPASV after: (a) acidifying to $\mathrm{pH} 2$ with $\mathrm{HNO}_{3}$; (b) acidifying to $\mathrm{pH} 2$ adding $\mathrm{H}_{2} \mathrm{O}_{2}$ and exposing to $\mathrm{UV}$ irradiation over $3 \mathrm{~h}$. In filtered samples, labile copper (c) was determined by DPASV after acidification with $\mathrm{HNO}_{3}$ at $\mathrm{pH} 2$ while dissolved copper (d) was obtained from acidified and UV irradiated samples. Organic copper and particulate copper were obtained from [(d) - (c)] and [(b) (d)], respectively. Complexing capacity was tested (wet season samples only) by adding $3.15 \mu \mathrm{mol} \mathrm{L^{-1 }} \mathrm{Cu}$ to $500 \mathrm{~mL}$, waiting $2 \mathrm{~h}$ for equilibration and then injecting the spiked sample through two Sep-Pak $\mathrm{C}_{18}$ cartridges connected in series. Copper complexes were eluted using $6 \mathrm{~mL}$ of methanol after washing the cartridges with $20 \mathrm{~mL}$ of Milli-Q water. A second set of cartridges treated as above was used to elute more polar copper complexes with a 1:1 methanol-water solution. The complete procedure was executed within 5 to $6 \mathrm{~h}$ after sampling. The methodology for complexing capacity determination described by Plasivic $^{23}$ and van den Berg ${ }^{24}$ was also applied to samples from station 12. For this, aliquots of the Nuclepore filtrate at ambient $\mathrm{pH}$ (6.24) were transferred to $20 \mathrm{~mL}$ polarographic Teflon cells and spiked with $320 \mathrm{nmol} \mathrm{L}^{-1}$, $630 \mathrm{nmol} \mathrm{L}^{-1}, 2360 \mathrm{nmol} \mathrm{L}{ }^{-1}$ and $6460 \mathrm{nmol} \mathrm{L}^{-1}$ of copper standard solution, respectively. The solutions rested for $12 \mathrm{~h}$ for equilibration before ASV analysis using Merck Suprapur $\mathrm{KCl}$ as supporting electrolyte. The same procedure was performed for an aliquot acidified at $\mathrm{pH} 1.8$ with Merck Suprapur $\mathrm{HNO}_{3}$. The complexing capacity and the "stability constant" were calculated following the method of Ruzic. ${ }^{25,26}$

All copper determinations were performed using Anodic Stripping Voltammetry (EG\&G 384 B Polarographic Analyzer coupled to an EG\&G 303 A HMDE) except for the organic extracts that were analyzed by GFAAS (Perkin Elmer 1100). The optimized ASV conditions were: initial potential, $-0.550 \mathrm{~V}$; final potential, $+0.180 \mathrm{~V}$; pulse height, $50 \mathrm{mV}$; scan rate, $4 \mathrm{mV} \mathrm{s}^{-1}$; scan increment, $2 \mathrm{mV}$; medium drop size; deposition times, 30 to $460 \mathrm{~s}$. We used the standard addition method for quantification and performed three determinations for each sample. Under these conditions the detection limit was $0.22 \mathrm{nmol} \mathrm{L}^{-1}$ and the standard deviation of the method, calculated from the results of three replicates, was $11 \%$ at

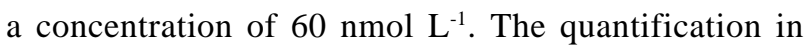


GFAAS was also made by the standard addition method using for each sample two replicate analysis. The detection limit for copper in this case was $0.2 \mathrm{nmol} \mathrm{L}^{-1}$.

Sampling and storage materials, filters, Teflon polarographic cells, Sep-Pak cartridges and polyethylene syringes were pre-cleaned as required for ultra-trace determination. Reagents were Merck Suprapur grade and the water used either for cleaning or in the tests was obtained from a Milli-RO/Milli-Q system. Storage bottles were protected with double polyethylene bags before and after sampling.

\section{Analytical procedures: sediments and other solids}

Sediments were dried at $50-60{ }^{\circ} \mathrm{C}$, ultra-sonically deaggregated, homogenized and sieved through Teflon sieves. To $0.5 \mathrm{~g}$ of the $<63 \mu \mathrm{m}$ fraction we added $10 \mathrm{~mL}$ of concentrated Merck p.a. $\mathrm{HNO}_{3}$ and heated at $80{ }^{\circ} \mathrm{C}$ for determination of acid extractable fractions of $\mathrm{Cu}, \mathrm{Fe}, \mathrm{Al}$, $\mathrm{Mn}, \mathrm{Ca}, \mathrm{Mg}, \mathrm{Na}$ and $\mathrm{K}$. The procedure of Eisenreich ${ }^{19}$ was applied to $1.0 \mathrm{~g}$ of sediment $(63 \mu \mathrm{m})$ for speciation of $\mathrm{Cu}$, $\mathrm{Fe}$ and $\mathrm{Mn}$. Through this we estimated the metal concentration bound to the following fractions: adsorbed/ exchangeable, after treatment over $7 \mathrm{~h}$ with $\mathrm{MgCl}_{2}$ $0.5 \mathrm{~mol} \mathrm{~L}^{-1}$; organic, after treatment over $10 \mathrm{~h}$ with $\mathrm{Na}_{4} \mathrm{P}_{2} \mathrm{O}_{7}$ $0.4 \mathrm{~mol} \mathrm{~L}^{-1}$ at $\mathrm{pH}$ 7; oxidized, after treatment over $30 \mathrm{~min}$ at $90^{\circ} \mathrm{C}$ with $\mathrm{HCl} 0.3 \mathrm{~mol} \mathrm{~L}^{-1}$; residual, after treatment over $12 \mathrm{~h}$ at $90^{\circ} \mathrm{C}$ with a 1:10:1 mixture of $\mathrm{HF}, \mathrm{HClO}_{4}$ and $\mathrm{H}_{2} \mathrm{O}_{2}$. Different fractions were separated by centrifugation prior to AAS analysis. All tests were run in duplicate. Other deter- minations on sediments were: gravimetric water content (drying at $105{ }^{\circ} \mathrm{C}$ ), organic carbon content (LECO CS244) and qualitative mineralogical composition by X-Ray Diffractometry (Phillips Diffractometer).

Samples of copper ore and solid waste, collected at the pilot plant, were pulverized and divided into two aliquots later used in the semi-quantitative analysis of main components by Emission Spectrography (RSV-SPN 3.5/ $500 \mathrm{Ph}$ ), and in the AAS determination of $\mathrm{Cu}, \mathrm{Na}, \mathrm{K}, \mathrm{Ca}$ and $\mathrm{Mg}$, after total digestion with $\mathrm{HClO}_{4}, \mathrm{HF}$ and $\mathrm{HCl}$.

\section{Results and Discussion}

Tables 1 to 5 show the experimental results obtained so far.

\section{Chemical properties of the waters}

As observed in several rivers of the Amazon region, ${ }^{7,810,15}$ concentration of major dissolved components is low compared to the average composition of North American and world rivers ${ }^{27}$ except for sodium. Sulfate in many samples from the dry season was below the detection limit. In general, there is no strong evidence of a decrease in cation concentration (Table 1) during the wet season. In some stations, concentrations were smaller in wet season samples but averages of all measured values for wet and dry season were not statistically different at the $95 \%$ significance level. However, chloride and nitrate concentration decreased significantly in the wet season,

Table 1. Concentration in $\mu \mathrm{mol} \mathrm{L}-1$ of major constituents in river waters. $\mathrm{P}=$ phosphate. Wet season: only stations 4,7 , 7A, 11-13 in the Salobo River; and stations $14,15,18$ in the Itacaiunas River

\begin{tabular}{|c|c|c|c|c|c|c|c|c|c|c|c|c|c|}
\hline \multirow[b]{2}{*}{ RIVERS } & \multicolumn{7}{|c|}{ DRY SEASON } & \multicolumn{6}{|c|}{ WET SEASON } \\
\hline & $\mathrm{Na}$ & $\mathrm{K}$ & $\mathrm{Ca}$ & $\mathrm{Mg}$ & $\mathrm{Cl}$ & Nitrate & $\mathrm{P}$ & $\mathrm{Na}$ & $\mathrm{K}$ & $\mathrm{Ca}$ & $\mathrm{Mg}$ & $\mathrm{Cl}$ & Nitrate \\
\hline \multicolumn{14}{|l|}{$\underline{\text { SALOBO }}$} \\
\hline Min. & 430.9 & 8.5 & 108.1 & 1.7 & 16.1 & 7.1 & $<\mathrm{dl}$ & 447.1 & 21.8 & 118.1 & 3.3 & 33.1 & 1.1 \\
\hline Max. & 572.2 & 32.8 & 234.5 & 11.3 & 188.2 & 26.9 & 16.6 & 481.3 & 46.9 & 204.1 & 6.7 & 97.8 & 15.5 \\
\hline Mean & 464.4 & 23.3 & 163.1 & 4.7 & 81.9 & 13.8 & 8.4 & 458.5 & 26.9 & 155.6 & 3.9 & 46.6 & 5.0 \\
\hline$\pm \mathrm{SD}$ & 44.8 & 6.1 & 33.5 & 2.8 & 47.8 & 6.3 & 4.0 & 13.8 & 9.8 & 32.4 & 1.4 & 25.2 & 5.2 \\
\hline Station 8 & 570.4 & 114.6 & 438.3 & 5.8 & 23.1 & 10.1 & 42.7 & 873.9 & 89.2 & 372.1 & 4.6 & 161.1 & 0.3 \\
\hline \multicolumn{14}{|l|}{ ITACAIUNAS } \\
\hline Min. & 573.1 & 54.6 & 169.8 & 4.2 & 66.5 & 2.7 & 9.9 & 527.4 & 36.9 & 166.5 & 4.6 & 16.1 & 0.8 \\
\hline Max. & 593.5 & 63.1 & 208.5 & 4.6 & 199.7 & 25.2 & 14.1 & 848.7 & 39.2 & 195.8 & 5.4 & 38.6 & 4.5 \\
\hline Mean & 585.1 & 59.3 & 191.5 & 4.4 & 99.9 & 13.9 & 11.9 & 649.3 & 37.8 & 178.5 & 5.0 & 30.2 & 3.1 \\
\hline$\pm \mathrm{SD}$ & 8.0 & 3.4 & 14.5 & 0.2 & 57.2 & 8.5 & 1.5 & 174.1 & 1.3 & 15.4 & 0.4 & 12.3 & 2.0 \\
\hline$\underline{\text { CINZENTO }}$ & 516.1 & 33.6 & 144.1 & 2.9 & 67.6 & 9.5 & 5.2 & 528.3 & 30.5 & 134.3 & 2.9 & 47.1 & 6.1 \\
\hline \multicolumn{14}{|l|}{ P. BAHIA } \\
\hline Min. & 332.2 & 9.5 & 98.8 & 2.1 & 59.4 & 10.2 & 4.1 & & & & & & \\
\hline Max. & 381.7 & 12.6 & 108.3 & 2.1 & 129.6 & 12.1 & 6.6 & & & & & & \\
\hline
\end{tabular}

$<\mathrm{dl}$ : below detection limit of $0.5 \mathrm{mmol} \mathrm{L}^{-1}$; * exploration gallery at the Salobo rim. 
inclusively in ground waters. The final concentration of a solute is associated, among other factors, to the different sources of material and to the ratio of surface to ground water flow. The constancy of major cation concentrations is a strong evidence that, on the average, the sub-surface runoff contributes a major fraction to the river flow. The absence of differences at the $99 \%$ significance level between concentrations in the Salobo River and in ground waters from the same region (wet season: sodium, $458.8 \pm$ $35.4 \mu \mathrm{mol} \mathrm{L} \mathrm{L}^{-1}$; potassium $43.2 \pm 16.7 \mu \mathrm{mol} \mathrm{L}{ }^{-1}$; calcium $135.3 \pm 45.0 \mu \mathrm{mol} \mathrm{L}{ }^{-1}$; magnesium, $4.6 \pm 2.2 \mu \mathrm{mol} \mathrm{L}{ }^{-1}$ ) supports this hypothesis. The observed variation of anion concentrations can be explained on the basis of additional sources, such as, surface soil and atmospheric inputs. Main sources of nitrate are at the soil surface (organic matter decomposition) although forest fires occurring during the dry season are certainly contributing to the nitrate input. For chloride and sulfate, additional sources may be marine and rain forest aerosols ${ }^{28}$ as well as biomass burning. ${ }^{29}$ The measured sulfate concentrations during the wet season (0.7$10 \mu \mathrm{mol} \mathrm{L}{ }^{-1}$ in the Salobo; $1-2 \mu \mathrm{mol} \mathrm{L}{ }^{-1}$ in the Itacaiunas; $0.7 \mu \mathrm{mol} \mathrm{L^{-1 }}$ in the Cinzento) are much too small to derive from weathering of the sulfide copper ore. Even at station 18, downstream the waste disposal site at Cinzento, we did not observed $\mathrm{pH}$ or sulfate levels indicative of contamination. Sulfate was below detection limit during the dry season.

The estimated ionic strength calculated using all measured concentrations including bicarbonate and carbonate ions ranged between $4 \times 10^{-4}-7 \times 10^{-4} \mathrm{~mol} \mathrm{~L}^{-1}$.
The main constituents are $\mathrm{Na}^{+}, \mathrm{Ca}^{2+}, \mathrm{HCO}_{3}{ }^{2-}$ and $\mathrm{Cl}^{-}$with concentrations of the order of hundredths to some tenths mmol L-1. The $\mathrm{pH}$ is generally slightly acid with exception of stations 2, 4 and 8 that presented slightly alkaline values in the dry season.

The charge balance $\left(\left[\mathrm{TZ}^{+}-\mathrm{TZ}^{-}\right] / \mathrm{TZ}^{+} ; \mathrm{TZ}^{+}=\mathrm{Na}^{+}+\mathrm{K}^{+}+\right.$ $\left.2 \mathrm{Ca}^{2+}+2 \mathrm{Mg}^{2+} ; \mathrm{TZ}^{-}=\mathrm{Cl}^{-}+\mathrm{HCO}_{3}{ }^{-}+2 \mathrm{SO}_{4}{ }^{2-}+\mathrm{NO}_{3}{ }^{-}\right)$indicate that there is an excess of cations over analyzed anions, as reported by Edmond et al. ${ }^{10}$ for rivers of the northwest Amazon. Charge balance indexes were between 0.08 and 0.8 and $\mathrm{TZ}^{+}$varied from $386 \mu \mathrm{eq} \mathrm{kg} \mathrm{kg}^{-1}$ (Pojuca) to $750 \mu \mathrm{eq} \mathrm{kg} \mathrm{kg}^{-1}$ (Itacaiunas river). In Salobo River $\mathrm{TZ}^{+}$was in the range of 552 to $690 \mu \mathrm{eq} \mathrm{kg}^{-1}$, except for station 8 where $\mathrm{TZ}^{+}=1151 \mu \mathrm{eq} \mathrm{kg}^{-1}$. The observed imbalance results from other anions and from organic acids not accounted for in the calculation of TZ. The dissolved organic carbon content in the Salobo region is relatively high $(\sim 300 \mu \mathrm{M} \mathrm{C}$, on the average), however, presently we have no means of estimating its contribution to the charge balance.

Carbonate alkalinity, calculated from DIC and $\mathrm{pH}$, ranged from $2.310^{-5} \mathrm{M}$ (Prospecto Bahia) to $9.3 \times 10^{-4} \mathrm{M}$ (Salobo, station 4) and the average in Salobo was $1.5 \times 10^{-4} \mathrm{M}$.

DOC (not measured in samples form the wet season) and DIC ranges are shown in Table 2. In the dry season the distribution pattern in the Salobo and the Itacaiunas rivers is quite different. In Salobo (stations 1 to 13) DIC dominates the carbon concentration while the highest values of DOC were present in the Itacaiunas. On the average, the dissolved carbon pool in the Itacaiunas $\left(13.51 \pm 2.36 \mathrm{mg} \mathrm{L}^{-1}\right)$ is $60 \%$ larger than in the Salobo $\left(8.33 \pm 2.79 \mathrm{mg} \mathrm{L}^{-1}\right)$. Samples

Table 2. $\mathrm{pH}$, dissolved organic carbon (DOC, $\mathrm{mg} \mathrm{L}^{-1}$ ), dissolved inorganic carbon (DIC, $\left.\mathrm{mg} \mathrm{L}^{-1}\right)$, concentration $\left(\mathrm{nmol} \mathrm{L}^{-1}\right)$ of total copper $(\mathrm{Cu}$ tot.), dissolved copper (Cu dis), particulate copper (Cu part) and particulate matter (PM, mg L $\mathrm{L}^{-1}$ ). Wet season: only stations 4, 7, 7A, 11-13 in the Salobo and 14, 15, 18 in the Itacaiunas

\begin{tabular}{|c|c|c|c|c|c|c|c|c|c|c|c|c|c|}
\hline \multirow[b]{2}{*}{ RIVERS } & \multicolumn{7}{|c|}{ DRY SEASON } & \multicolumn{6}{|c|}{ WET SEASON } \\
\hline & $\mathrm{pH}$ & DOC & DIC & $\begin{array}{l}\mathrm{Cu} \\
\mathrm{dis}\end{array}$ & $\begin{array}{c}\mathrm{Cu} \\
\text { part }\end{array}$ & $\begin{array}{c}\mathrm{Cu} \\
\text { total }\end{array}$ & PM & $\mathrm{pH}$ & DIC & $\begin{array}{l}\mathrm{Cu} \\
\mathrm{dis}\end{array}$ & $\begin{array}{c}\mathrm{Cu} \\
\text { part }\end{array}$ & $\begin{array}{c}\mathrm{Cu} \\
\text { total }\end{array}$ & $\mathrm{PM}$ \\
\hline \multicolumn{14}{|l|}{$\underline{\text { SALOBO }}$} \\
\hline Min. & 5.44 & $<\mathrm{dl}$ & 0.08 & 13.2 & 8.8 & 43.8 & 1.31 & 6.24 & 0.54 & 28.5 & 4.3 & 32.7 & 4.14 \\
\hline Max. & 7.41 & 5.68 & 11.30 & 207.1 & 107.6 & 160.2 & 11.56 & 7.09 & 3.34 & 80.4 & 274.9 & 315.4 & 11.81 \\
\hline Mean & 6.49 & 3.12 & 4.63 & 50.5 & 31.3 & 70.9 & 7.07 & 6.54 & 2.36 & 51.5 & 74.1 & 125.6 & 7.96 \\
\hline$\pm \mathrm{SD}$ & 0.51 & 1.23 & 3.05 & 50.5 & 32.3 & 37.9 & 3.35 & 0.32 & 0.99 & 18.8 & 102.5 & 102.1 & 3.05 \\
\hline Station 8 & 7.41 & 2.63 & 10.32 & 60.6 & 196.3 & 256.9 & 27.23 & 6.45 & 3.28 & 48.3 & 261.4 & 309.7 & 153.34 \\
\hline \multicolumn{14}{|l|}{ ITACAIUNAS } \\
\hline Min. & 6.39 & 4.58 & 4.47 & 24.2 & 2.4 & 35.1 & 17.52 & 6.52 & 2.34 & 16.7 & 23.8 & 66.4 & 7.51 \\
\hline Max. & 6.95 & 9.55 & 8.06 & 75.7 & 42.1 & 102.6 & 28.12 & 7.31 & 5.69 & 60.1 & 49.7 & 91.4 & 8.51 \\
\hline Mean & 6.75 & 7.23 & 6.11 & 51.3 & 12.5 & 63.8 & 23.20 & 6.88 & 3.69 & 40.8 & 39.8 & 80.5 & 8.01 \\
\hline$\pm \mathrm{SD}$ & 0.22 & 2.16 & 1.73 & 20.5 & 16.9 & 27.8 & 4.72 & 0.40 & 1.77 & 22.1 & 13.9 & 12.8 & 0.50 \\
\hline CINZENTO & 6.66 & 8.96 & 4.57 & 60.4 & & & 20.62 & 6.72 & & 31.1 & 36.8 & 67.8 & 15.51 \\
\hline \multicolumn{14}{|l|}{ P. BAHIA } \\
\hline Min. & 5.58 & & 2.11 & 37.8 & 5.5 & 70.2 & 3.58 & & & & & & \\
\hline Max. & 6.31 & $<\mathrm{dl}$ & 3.31 & 127.1 & 32.4 & 132.5 & 17.16 & & & & & & \\
\hline
\end{tabular}

$\left\langle\mathrm{dl}\right.$ :detection limit of $0.1 \mathrm{mg} \mathrm{L} \mathrm{L}^{-1}$ 
collected in the wet season show a remarkably lower DIC both in the Salobo and the Itacaiunas rivers most probably due to dilution effect. Itacaiunas also presented higher particulate load as compared to Salobo during the dry season. In the wet season, a decrease in particulate matter by $20 \%$ to more than $50 \%$ is observed especially in the Itacaiunas. However, in station 8, at the mouth of the exploration gallery, particulate matter increases from 27.23 $\mathrm{mg} \mathrm{L}^{-1}$ in the dry season to $153.34 \mathrm{mg} \mathrm{L}^{-1}$ in the wet season due to the intensive erosion of the denudated soil. The output from station 8 has a strong influence on stations 7 and $7 \mathrm{~A}$ where particulate matter concentration doubles during the wet season. Organic material makes up only a very small fraction $(0.16$ to $0.78 \%$ ) of the particulate matter, showing a tendency to smaller values in the wet season. This reduced organic contribution is in accordance with the low organic matter content, $1-2 \%$, of soils in the region. ${ }^{30}$

\section{Copper concentration and speciation in waters}

Tables 2 and 3 show the results for copper speciation. The total copper distribution along the Salobo suggests a natural source of copper at the Salobo spring (station 1) where concentrations are significantly higher than in the other pristine area. The natural background concentration is around $50-60 \mathrm{nmol} \mathrm{L}^{-1}$, a relatively high value that

Table 3. Concentrations ( $\left.\mathrm{nmol} \mathrm{L} \mathrm{L}^{-1}\right)$ of labile copper $(\mathrm{Cu}$ dis labile), dissolved organic copper $(\mathrm{Cu}$ dis org) and copper at the natural $\mathrm{pH}(\mathrm{Cu} \mathrm{pH}$ nat) in river water. Wet season: only stations 4, 7, 7A, 11-13 in the Salobo and stations 14, 1518 in the Itacaiunas

\begin{tabular}{|c|c|c|c|c|c|c|}
\hline \multirow[b]{2}{*}{ RIVERS } & \multicolumn{3}{|c|}{ DRY SEASON } & \multicolumn{3}{|c|}{ WET SEASON } \\
\hline & $\mathrm{Cu}$ dis labile & $\mathrm{Cu}$ dis org & $\mathrm{Cu} \mathrm{pH}$ nat & $\mathrm{Cu}$ dis labile & $\mathrm{Cu}$ dis org & $\mathrm{Cu} \mathrm{pH}$ nat \\
\hline \multicolumn{7}{|l|}{$\underline{\text { SALOBO }}$} \\
\hline Min. & 3.2 & $<\mathrm{dl}$ & 10.9 & 3.2 & 6.9 & 21.6 \\
\hline Max. & $178.8^{1}$ & 32.4 & $302.7^{1}$ & $69.9^{1}$ & 36.2 & $233.7^{2}$ \\
\hline Mean & 37.0 & 15.5 & 55.5 & 43.8 & 18.1 & 100.8 \\
\hline$\pm \mathrm{SD}$ & 44.5 & 10.6 & 75.8 & 23.5 & 11.8 & 73.8 \\
\hline Station 8 & 52.4 & 8.2 & 226.2 & 35.4 & 12.9 & 292.3 \\
\hline \multicolumn{7}{|l|}{ ITACAIUNAS } \\
\hline Min. & 5.7 & 5.2 & 21.9 & 8.3 & $<\mathrm{dl}$ & 25.3 \\
\hline Max. & 53.5 & 70.1 & 66.4 & 61.7 & 8.3 & 47.4 \\
\hline Mean & 22.9 & 28.4 & 42.3 & 38.8 & & 38.6 \\
\hline$\pm \mathrm{SD}$ & 19.3 & 30.7 & 17.5 & 27.5 & & 11.7 \\
\hline CINZENTO & 49.9 & 10.5 & 57.1 & 23.3 & 7.7 & 63.9 \\
\hline \multicolumn{7}{|l|}{ P. BAHIA } \\
\hline Min. & 35.9 & 1.9 & 44.5 & & & \\
\hline Max. & 111.6 & 15.4 & 122.1 & & & \\
\hline
\end{tabular}

$<\mathrm{dl}=$ below detection limit of $0.22 \mathrm{nmol} \mathrm{L-1} ;{ }^{1}$ station $7 \mathrm{~A} ;{ }^{2}$ station 7

Table 4. Aluminum, iron and manganese concentrations $\left(\mathrm{mg} \cdot \mathrm{g}^{-1}\right)$ in particulate matter

\begin{tabular}{|c|c|c|c|c|c|c|}
\hline \multirow[b]{2}{*}{ RIVERS } & \multicolumn{3}{|c|}{ DRY SEASON } & \multicolumn{3}{|c|}{ WET SEASON } \\
\hline & $\mathrm{Al}$ & $\mathrm{Fe}$ & $\mathrm{Mn}$ & $\mathrm{Al}$ & $\mathrm{Fe}$ & $\mathrm{Mn}$ \\
\hline \multicolumn{7}{|l|}{ SALOBO } \\
\hline Min. & 3.2 & 8.4 & 0.23 & 3.5 & 9.1 & 0.08 \\
\hline Max. & 6.3 & 14.8 & 0.41 & 8.1 & 17.6 & 0.13 \\
\hline Mean & 4.8 & 10.7 & 0.28 & 5.2 & 11.6 & 0.11 \\
\hline$\pm \mathrm{SD}$ & 1.4 & 2.5 & 0.07 & 1.8 & 3.0 & 0.02 \\
\hline \multicolumn{7}{|l|}{ ITACAIUNAS } \\
\hline Min. & 7.8 & 4.2 & 0.06 & 5.5 & 5.3 & 0.11 \\
\hline Max. & 12.9 & 6.8 & 0.13 & 6.2 & 7.5 & 0.16 \\
\hline Mean & 11.1 & 5.6 & 0.10 & 5.8 & 6.4 & 0.13 \\
\hline$\pm \mathrm{SD}$ & 1.9 & 0.9 & 0.03 & 0.4 & 1.1 & 0.02 \\
\hline CINZENTO & 10.2 & 7.9 & 0.19 & 8.7 & 8.1 & 0.16 \\
\hline P. BAHIA & 12.4 & 11.2 & 0.11 & & & \\
\hline
\end{tabular}


concurs with the geology of the area. The gallery output (station 8) seems to be the main source of copper from anthropogenic activities to the river as can be concluded from the extremely high total copper concentrations encountered in the nearby stations $7\left(315.4 \mathrm{nmol} \mathrm{L}^{-1}\right)$ and 7A (110.2 $\left.\mathrm{nmol} \mathrm{L}^{-1}\right)$ in the wet season. In this season, concentrations up to three times the background values were found all the way down to station 11, situated about $2 \mathrm{~km}$ downstream of the pilot plant.

In Igarape Mirim (station 9) we measured the lowest total copper concentration of the survey area, equal to $13.2 \mathrm{nmol} \mathrm{L}^{-1}$. Station 14, at the mouth of the Salobo River, shows concentrations above the average of the other sites in the Itacaiunas River, both in the dry and wet seasons, probably resulting from the environmental disturbances upstream in the Salobo.

The molar ratio of labile copper to dissolved calcium is $2.8 \times 10^{-4} \pm 3.1 \times 10^{-4}$ in the dry season and $2.2 \times 10^{-4} \pm 1.9 \times 10^{-4}$ in the wet season. These results confirm that ground water is a major source of cations to the river system, including copper. The above ratio in ground waters ranges between $6 \times 10^{-3}$ and $14 \times 10^{-3}$. The one order of magnitude difference between the ratio in surface water and in ground water may result from copper sorption on soil particles and sediments when water migrates from the aquifer to the river.

Except for stations 1 and 8, in the dry season, the major fraction of copper is in the "dissolved state" which here includes colloidal material. Station 8 seems to be an important source of particulate copper. There the particulate fraction $\left(196.3 \mathrm{nmol} \mathrm{L}^{-1}\right.$ in the dry season to $309.7 \mathrm{nmol} \mathrm{L}^{-1}$ in the wet season) is 3 times the dissolved copper value $\left.\left(\mathrm{Cu}_{\mathrm{dis}}=60.6 \mathrm{nmol} \mathrm{L}\right)^{-1}\right)$ in the dry season, and 6 times in the wet season $\left(\mathrm{Cu}_{\mathrm{dis}}=48.3 \mathrm{nmol} \mathrm{L}^{-1}\right)$. Station 11 shows a strong increase in particulate copper in the wet season probably derived from the output of the exploration gallery area. In the Itacaiunas, the particulate copper is only about $10 \%$ of the "dissolved copper" in the dry season except for station $14(70 \%)$ that is evidently influenced by the activities in the Salobo, and station 18 located downstream the mouth of the Cinzento River. Although in the wet season particulate matter concentration decreases in the Itacaiunas, the total particulate copper and the ratio of particulate to dissolved copper increases most probably due to a substantial input of copper enriched material from the Salobo. There is no correlation between the concentration of particulate copper and total particulate or organic particulate matter.

For some stations we calculated "sorbed copper" as the difference between "labile copper" and the copper concentration measured in unfiltered samples at $\mathrm{pH} 2$ (sorbed copper). For station $8,88 \%$ and $98 \%$ of the particulate copper in the dry and wet season, respectively, became available to the voltammetric determination by acidification at $\mathrm{pH} 2$. In station 7 the "sorbed" concentration increases from $8.5 \mathrm{nmol} \mathrm{L}{ }^{-1}$ to $200 \mathrm{nmol} \mathrm{L}-1$ from the dry to the wet season ( $63 \%$ adsorbed). The same trend is observed for station 11 with "sorbed" concentrations increasing from $3.6 \mathrm{nmol} \mathrm{L}^{-1}(28 \%)$ to $86.6 \mathrm{nmol} \mathrm{L}^{-1}(97 \%)$. Evidently, the denudation of soils related to the mining activities results in continuous release of particulate matter containing a higher fraction of weakly bound copper as compared to the natural situation.

The Bahia, Aguas Claras and Pojuca Igarapes are at about $12 \mathrm{~km}$ south of the mouth of the Salobo River and are not connected to it or to the Itacaiunas. In the area of Bahia Igarape (stations B1 and B2) there are occurrences of copper but no mining activities. Station B1 is downstream of a small dam constructed for water storage and shows an average total copper concentration (132.5 nmol L-1 of which $96 \%$ is "dissolved") comparable to that of station 1 in Salobo. In station B2, as well as in the other two Igarapes, copper concentration is in the background range found for the Salobo (60 to $70 \mathrm{nmol} \mathrm{L}^{-1}$ ) with 50 to $60 \%$ of dissolved copper.

As for the speciation of "dissolved copper", "labile copper" predominates in the majority of the observed sites and in some of the samples "non-labile" copper, that includes ASV inert copper complexes and copper bound to colloidal iron or manganese oxides reducible under UV irradiation, was below the detection limit. There is no correlation between DOC and any of the dissolved copper fractions. In Bahia and Pojuca Igarapes more than $80 \%$ of the "dissolved copper" is "labile" while in Aguas Claras this fraction drops to $30 \%$. Although conditions are variable from river to river and from station to station there is a general tendency of copper to appear in the "dissolved labile" fraction in sites under natural conditions. Peaks of particulate copper are associated with sites under influence of the pilot plant.

For a number of stations we calculated the distribution of inorganic species of copper using the "labile" copper concentration, the major constituent concentration, $\mathrm{pH}$, DIC and the equations and equilibrium constants given below:

$$
\begin{aligned}
& \mathrm{Cu}_{\mathrm{T}}=\left[\mathrm{Cu}^{2+}\right]+\left[\mathrm{CuOH}^{+}\right]+\left[\mathrm{Cu}(\mathrm{OH})_{2}\right]+\left[\mathrm{CuCO}_{3}\right]+ \\
& {\left[\left(\mathrm{CuCO}_{3}\right)^{2-}\right]+\left[\mathrm{CuSO}_{4}\right]+\left[\mathrm{CuCl}^{+}\right]} \\
& \mathrm{CO}_{3 \mathrm{~T}}=\left[\mathrm{CO}_{3}{ }^{=}\right]+\left[\mathrm{CaCO}_{3}\right]+\left[\mathrm{CaHCO}_{3}{ }^{+}\right]+\left[\mathrm{MgCO}_{3}\right]+ \\
& {\left[\mathrm{MgHCO}_{3}^{-}\right]+\left[\mathrm{NaCO}_{3}^{-}\right]+\left[\mathrm{NaHCO}_{3}\right]} \\
& \mathrm{SO}_{4 \mathrm{~T}}=\left[\mathrm{SO}_{4}{ }^{-}\right]+\left[\mathrm{HSO}_{4}^{-}\right]+\left[\mathrm{MgSO}_{4}\right]+\left[\mathrm{CaSO}_{4}\right] \\
& \text { Copper: } \log \beta_{\mathrm{CuOH}}=6.5 ; \log \beta_{\mathrm{Cu}(\mathrm{OH})_{2}}=11.8 ; \log \beta_{\mathrm{CuCO}_{3}}= \\
& 6.7 ; \beta_{\mathrm{Cu}\left(\mathrm{CO}_{3}\right)_{2}}=10.2 ; \log \beta_{\mathrm{CuSO}_{4}}=2.4 ; \log \beta_{\mathrm{CuCl}}=0.5(\mathrm{in}
\end{aligned}
$$


Carbonate and sulfate: carbonic acid $\mathrm{pK}_{1}=6.35$ and $\mathrm{pK}_{2}=10.33 ; \log \mathrm{K}_{\mathrm{HSO}_{4}}=1.99 ; \log \beta_{\mathrm{CaCO}_{3}}=3.2 ; \log \beta_{\mathrm{CaHCO}_{3}}$ $=11.59 ; \log \beta_{\mathrm{CaSO}_{4}}=2.31 ; \log \beta_{\mathrm{MgCO}_{3}}=3.4 ; \log \beta_{\mathrm{MgHCO}_{3}}=$ $11.49 ; \log \beta_{\mathrm{MgSO}_{4}}=2.36 ; \log \beta_{\mathrm{NaCO}_{3}{ }^{-}}^{=} 1.27 ; \log \beta_{\mathrm{NaHCO}_{3}}=$ 10.08 (in Morel). ${ }^{27}$

Ionic copper makes up the major fraction of the dissolved inorganic copper in the wet season (from 55\% in station 4 to $90 \%$ in station $7 \mathrm{~A}$ and 11), and the carbonate ion is the main inorganic ligand. In addition, small variations in $\mathrm{pH}$ lead to significant changes in speciation because of the second order carbonate concentration dependence on $\left[\mathrm{H}^{+}\right]$. Changes in speciation that may be of seasonal character derive principally from the combined effect of $\mathrm{pH}$ and inorganic carbon (smaller values in the wet season) variations. In samples from stations $7 \mathrm{~A}$ and 11 , which are influenced by activities at the pilot plant, about $90 \%$ of the dissolved inorganic copper is in the free ionic form both in the dry and wet season.

The complexing capacity calculated from voltammetric experiments $\left(1.7 \mu \mathrm{mol} \mathrm{L}^{-1}\right)$ as well as the derived apparent complexation constant $(\log \mathrm{K}=6.26)$ are in the range of data reported by other authors (e.g. in Buffle ${ }^{31}$ ) for fresh water of pH slightly above 6.0 and DOC of $4 \mathrm{mg} \mathrm{L}^{-1}$. The complexing capacities determined using the SEP-PAK C18 copper extraction varied from $28 \%$ at station 19 to $90 \%$ at station 7 . The high value of copper bound $(90 \%)$ in station 7 compared to other stations may result from the anthropic activities, for example, forest clearing, which increase the provision of additional soluble and colloidal binding sites. Leaching from the xanthate treatment waste may contribute to increased complexing capacity in station 7. Although DOC data are not available for the wet season, lower values than in the dry season can be expected because of dilution. Since in station 7 DOC was below the detection limit in the dry season, it is reasonable to assume that colloidal iron oxides account for most of the measured complexing capacity. Both the high values of particulate $\mathrm{Fe}$ and $\mathrm{Mn}$ and the predominance of more polar binding sites in station 7 (copper in the methanol-water fraction: 77 $\%$ in station 7; $93 \%$ in station $14 ; 50-60 \%$ in stations 12 , 13,15 and 19) reinforce this assumption.

The two Itacaiunas stations (S15 and S18), upstream the Salobo confluence, show lower complexing capacities and equal copper partitioning between methanol (nonpolar compounds) and methanol-water (semi-polar compounds) extraction. There, DOC values in the dry season were substantially greater than in the Salobo.

Although complexing capacities of some units of $\mu$ mol L ${ }^{-1}$ should be sufficient to bind a significant portion of the available dissolved copper $\left(\sim 10^{-2} \mu \mathrm{mol} \mathrm{L}^{-1}\right)$, speciation results show that, at the original copper levels in the water samples, binding sites are unavailable, possibly due to successful competition of hydrogen, calcium and other ions for these sites.

\section{Copper concentration and speciation in sediments}

Sediment mineralogy comprises chlorite, kaolinite, Kfeldspar, vermiculite, quartz, serpentines, mica and hematite. Other minerals were rutile, illite and plagioclase as accessories. Itacaiunas sediments are enriched in organic carbon $(5.15-9.09 \%)$ compared to those from Salobo $(0.60-4.10 \%)$ and, in general, organic carbon content in the dry season was smaller than in the wet season. There is no relation between organic carbon content and total copper concentration in sediments.

Copper concentration in the Salobo sediments (Table 5) decreases dramatically during the wet season, especially in stations $7 \mathrm{~A}$ ( $1.74 \mathrm{mg} \mathrm{g}^{-1}$ dry season to $0.64 \mathrm{mg} \mathrm{g}^{-1}$ wet season) and 8 (5.62 $\mathrm{mg} \mathrm{g}^{-1}$ dry season to $0.94 \mathrm{mg} \mathrm{g}^{-1}$ wet season). Average iron concentration decreases from $4.78 \pm 1.37 \%$ in the dry season to $1.82 \pm 1.19 \%$ (except at station 8 ) in the wet season while aluminum increases from $1.11 \pm 0.66 \%$ to $4.35 \pm 1.63 \%$ (except at station 8 ). Copper seems to be carried away bound to fine lateritic iron particles while strong weathering of kaolinite rich clay soils during the wet period may account for the observed enrichment in aluminum. The increase in sodium, from $36.3 \pm 17.6 \mu \mathrm{g} \mathrm{g}^{-1}$ in the dry season to $220 \pm 85 \mu \mathrm{g} \mathrm{g}^{-1}$ in the wet season, is an additional indication of this substitution. The material carried down is in part deposited in the vicinity of the Salobo-Itacaiunas confluence as indicated by the increase in copper and iron concentrations at stations 14 and 15 .

In the Salobo and Itaciaunas, the ratio of $\mathrm{Cu} / \mathrm{Al}$ in the sites not immediately influenced by mining activities is in the range of $30-100 \times 10^{-4}$. Mining activities resulted in large increase of the $\mathrm{Cu} / \mathrm{Al}$ ratio as observed in stations 7 $\left(2.836 \times 10^{-4}\right), 8\left(5.301 \times 10^{-4}\right)$ and 7A $\left(10.260 \times 10^{-4}\right)$. Ratios larger than $100 \times 10^{-4}$ under natural conditions, as, for example, at stations 1, 2, B1 and B2, may be good indicators of copper ore in the vicinity of the sampling site. Other ionic ratios of interest as indicators of alterations are the $\mathrm{Cu} / \mathrm{Mn}$ and $\mathrm{Cu} / \mathrm{Na}$ ratios. In the specific case of Salobo the ratio $\mathrm{Cu} / \mathrm{Mn}$ appears to be a good indicator of copper anomalies due to the small variations observed in manganese concentrations. The $\mathrm{Cu} / \mathrm{Na}$ ratio was 0.68 in copper containing minerals and 0.32 in wastes, while in sediments from less disturbed sites ratios were, in general, larger than 1 . These differences point out an ongoing process of copper enrichment in sediments as compared to the main copper sources. In stations 8 and $7 \mathrm{~A}, \mathrm{Cu} / \mathrm{Na}$ ratios, which in the dry season were 74 and 53, respectively, 
Table 5. Concentrations of copper $\left(\mathrm{mg} \mathrm{g}^{-1}\right)$, sodium $\left(\mathrm{mg} \mathrm{g}^{-1}\right)$, potassium $(\%)$, calcium $(\%)$, magnesium $(\%)$, aluminum (\%), iron (\%), manganese $(\%)$ and organic carbon $\left.\mathrm{C}_{\mathrm{org}} ; \%\right)$ in river sediment. Wet season: only stations 4, 7, 7A, 11-13 in the Salobo and 14,15, 18 in the Itacaiunas

\begin{tabular}{|c|c|c|c|c|c|c|c|c|c|}
\hline \multirow[b]{2}{*}{ RIVERS } & \multicolumn{9}{|c|}{ DRY SEASON } \\
\hline & $\mathrm{C}_{\text {org }}$ & $\mathrm{Cu}$ & $\mathrm{Na}$ & $\mathrm{K}$ & $\mathrm{Ca}$ & $\mathrm{Mg}$ & $\mathrm{Al}$ & $\mathrm{Fe}$ & $\mathrm{Mn}$ \\
\hline \multicolumn{10}{|l|}{$\underline{\text { SALOBO }}$} \\
\hline Min. & 0.61 & 0.061 & 0.021 & 0.02 & 0.06 & 0.02 & 0.09 & 2.82 & 0.05 \\
\hline Max. & 8.34 & 1.744 & 0.075 & 0.16 & 0.21 & 0.21 & 2.23 & 6.95 & 0.28 \\
\hline Mean & 2.11 & 0.316 & 0.054 & 0.05 & 0.12 & 0.05 & 1.12 & 4.78 & 0.09 \\
\hline$\pm \mathrm{SD}$ & 2.00 & 0.483 & 0.043 & 0.05 & 0.06 & 0.05 & 0.68 & 1.37 & 0.06 \\
\hline Station 8 & 1.87 & 5.619 & 0.075 & 0.13 & 0.68 & 0.13 & 1.06 & 34.24 & 1.82 \\
\hline \multicolumn{10}{|l|}{ ITACAIUNAS } \\
\hline Min. & 1.27 & 0.018 & 0.016 & 0.03 & 0.04 & 0.02 & 0.56 & 0.16 & 0.01 \\
\hline Max. & 1.94 & 0.056 & 0.054 & 0.05 & 0.12 & 0.04 & 1.58 & 2.36 & 0.05 \\
\hline Mean & 1.53 & 0.031 & 0.033 & 0.05 & 0.09 & 0.03 & 1.12 & 1.30 & 0.03 \\
\hline$\pm \mathrm{SD}$ & 0.29 & 0.015 & 0.016 & 0.01 & 0.04 & 0.01 & 0.43 & 0.89 & 0.02 \\
\hline CINZENTO & 1.30 & 0.031 & 0.027 & 0.02 & 0.04 & 0.01 & 1.01 & 1.57 & 0.03 \\
\hline \multicolumn{10}{|l|}{ P. BAHIA } \\
\hline Min. & 1.99 & 0.198 & 0.027 & 0.04 & 0.09 & 0.02 & 1.67 & 4.80 & 0.04 \\
\hline \multirow[t]{2}{*}{ Max. } & 5.26 & 0.428 & 0.054 & 0.06 & 0.12 & 0.03 & 4.69 & 12.87 & 0.05 \\
\hline & \multicolumn{9}{|c|}{ WET SEASON } \\
\hline RIVERS & $\mathrm{C}_{\text {org }}$ & $\mathrm{Cu}$ & $\mathrm{Na}$ & $\mathrm{K}$ & $\mathrm{Ca}$ & $\mathrm{Mg}$ & $\mathrm{Al}$ & $\mathrm{Fe}$ & $\mathrm{Mn}$ \\
\hline \multicolumn{10}{|l|}{$\underline{\text { SALOBO }}$} \\
\hline Min. & 1.20 & 0.078 & $0.143<$ & dl & 0.04 & 0.04 & 2.63 & 1.07 & 0.02 \\
\hline Max. & 4.11 & 0.639 & 0.318 & 0.03 & 0.15 & 0.09 & 6.71 & 4.08 & 0.22 \\
\hline Mean & 2.29 & 0.254 & 0.196 & 0.02 & 0.08 & 0.05 & 4.34 & 2.02 & 0.10 \\
\hline$\pm \mathrm{SD}$ & 1.11 & 0.232 & 0.062 & 0.01 & 0.05 & 0.02 & 1.63 & 1.18 & 0.08 \\
\hline Station 8 & 0.87 & 0.938 & 0.365 & 0.09 & 0.42 & 0.11 & 31.11 & 0.64 & 1.27 \\
\hline \multicolumn{10}{|l|}{ ITACAIUNAS } \\
\hline Min. & 1.51 & 0.063 & 0.103 & 0.03 & 0.01 & 0.04 & 1.68 & 1.06 & 0.02 \\
\hline Max. & 2.31 & 0.107 & 0.283 & 0.01 & 0.50 & 0.06 & 2.19 & 1.86 & 0.05 \\
\hline Mean & 1.98 & 0.092 & 0.207 & 0.02 & 0.18 & 0.05 & 1.90 & 1.48 & 0.04 \\
\hline$\pm \mathrm{SD}$ & 0.42 & 0.025 & 0.093 & 0.01 & 0.28 & 0.01 & 0.26 & 0.40 & 0.02 \\
\hline CINZENTO & 2.11 & 0.038 & 0.106 & 0.02 & 0.02 & 0.02 & 0.06 & 1.19 & 0.03 \\
\hline \multicolumn{10}{|l|}{ P. BAHIA } \\
\hline \multicolumn{10}{|l|}{ Min. } \\
\hline Max. & & & & & & & & & \\
\hline
\end{tabular}

decreased to 2.6 and 4.5 in the wet season. The observed decrease derives both from the wash out of copper and from an increase in sodium concentration.

In the particulate matter collected during the dry season $\mathrm{Cu} / \mathrm{Al}, \mathrm{Cu} / \mathrm{Fe}$ and $\mathrm{Cu} / \mathrm{Mn}$ ratios were slightly greater than those for sediments. However, in the wet season, ratios in the particulate matter are at least one order of magnitude larger, most probably, due to re-suspension and transport of finer particles, rich in copper. This effect is dramatic in stations 8 and 7A where the increase in particulate copper during the wet season is coupled with a significant decrease in sediment copper.

Copper speciation in sediment has been also affected by human activities. In station 7A there is a substantial fraction of copper associated with the "labile fractions" ("adsorbed"
+ "organic" + oxidized" = 51\%) compared with the less disturbed station 7 (21\%) where copper appears mainly bound to the "residual fraction" (79\%). The preference for the "residual fraction" increases again downstream in the Salobo with increasing distance from the plant $(49 \%$ in station 12 , $58 \%$ in station 14 and $64 \%$ in station 15 ).

\section{Conclusions}

The present work provides baseline data for future impact assessment and information on existing environmental alterations for one of the most important mining provinces in the Amazon region.

The nature of the water chemistry in the observed area characterizes a hydrological system of low capacity to 
buffer possible effects of anthropogenic copper on the existing biota. The inorganic speciation in waters demonstrated that the reduced levels of ligands like chloride and carbonate, the slightly acid $\mathrm{pH}$ and the presence of calcium concentrations of about $10^{-4} \mathrm{~mol} \mathrm{~L}^{-1}$ (along with an excess of cations over inorganic anions) lead to a low availability of inorganic binding sites for copper. The organic complexing capacity effective at the low natural copper concentrations seems to be smaller than that obtained experimentally after spiking the water samples with high copper concentrations, a procedure that alters the ratio of copper to other competing ions. This is reflected in the predominance of "labile copper" in most of the samples and derives from the competition for the binding sites, for instance, of hydrogen and calcium ions (iron, not measured here, may also be effective), present in higher concentrations. Although the number of sampling campaigns is small to allow conclusions about seasonal behavior, the results point out to a significant change in speciation from the dry to the wet period.

In undisturbed sites, the forested soil maintains particulate matter loads in the Salobo river within the range of 2 to $10 \mathrm{mg} \mathrm{L}^{-1}$. Significant increase in particulate loads and copper mobilization are observed in areas where the soil has been exposed. Alterations in water and sediment chemistry derived from this process are measurable in the Salobo, adjacent to the mining plant, and in the further away Itacaiunas, a major river in the region. Although we are not yet able to forecast quantitative changes under the future large open pit mining operations, some critical environmental disturbances already going on will be strengthened, as for instance, the increase in total dissolved solids and particulate matter. A very important question to consider in the future is the influence of coming activities on $\mathrm{pH}$ and sulfate concentration. From our data we conclude that for the time being there is no measurable impact in the water system derived from sulfide oxidation, a situation that may be different under large-scale operation.

The actual impact of the pilot scale operation on the copper content in Salobo waters can be roughly estimated by comparing the average copper concentration found in stations upstream of the plant with the average of those stations downstream the plant. The observed relative increase ranges from about $50 \%$ in the dry season to more than $100 \%$ in the wet season.

We used total copper concentration and the average flow rate of $2 \mathrm{~m}^{3} \mathrm{~s}^{-1}$ (dry season) estimated from the river width, depth and speed at each sampling station, to calculate the present transport of copper at seven stations along the Salobo River. There is no significant change in copper transport along the river extension and the total transport during the dry season is close to $25 \mathrm{~kg} \mathrm{Cu}$ month $^{-1}$. The fixation rate in sediments must be small compared to the rate of water transport. The water regime plays an important role in controlling copper fixation in sediments as demonstrated by the lower $\mathrm{Cu}$ concentrations found at the end of the wet period. Weathering processes and re-suspension of sediments, intensified during this period, also affect speciation of copper in water, resulting in remarkable increase in inorganic and labile copper together with particulate copper. During the wet season when flow rates are at least 3 times higher and average concentrations increase, total transport can reach more than $100 \mathrm{~kg} \mathrm{Cu}$ month $^{-1}$.

The observations and conclusions drawn here may apply to other tropical rivers characterized by the presence of neutral to acidic waters, low chloride content and organic carbon concentration between 2 to $4 \mathrm{mg} \mathrm{L}^{-1}$. Copper speciation, however, may change drastically in the frequently found situation of rivers subjected to domestic sewage release. In this case contribution of additional organic ligands may reduce copper availability and toxicity to primary producers. ${ }^{32}$

\section{Acknowledgements}

Authors are grateful to CAPES and to the PADCT programme that financed the present work, as well as to Vale do Rio Doce Company that provided logistic support.

\section{References}

1. Biesiegel, V. de R.; Bernardinelli, A.L.; Drumond, N.F; Ruff, A.W.; Traine, J.W.; Rev. Bras. de Geociên. 1973, 3, 215.

2. CVRD / SUPES / GICOR, Cia. Vale do Rio Doce; Relatório Preliminar de Meio Ambiente do Projeto Cobre-Carajás, $R L$ 589-C-91-0001, Belém, Brazil, 1986, p. 7, 9, 18, 21.

3. Toledo-Groke, M. C.; Prost, D.; Ildefonse, P.; Melfi, A.J.; Delvigne, J.; Parisot, J. C.; Rev. Bras. de Geociên. 1985, 15, 239.

4. DOCEGEO, Rio Doce Geologia e Mineração; Projeto CobreCarajás, Jazidas Salobo 3A e 4A, Relatório de Pesquisa. Belém, Brazil, 1981, v. 4.

5. Ramos, J. F. da F.; Anais do II Simpósio de Geologia da Amazônia. Belém, Brazil, 1985.

6. Viana, A. ; Farias, N.; Saueressig, R.; Rev. Ciên. da Terra, 1982, 5, 13.

7. Stallard, R. F.; Edmond, J. M.; J. Geophys. Res. 1981, 86, 9844.

8. Stallard, R. F.; Edmond, J. M.; J. Geophys. Res. 1983, 88, 9671. 
9. Boyle, E. A.; Huested, S.S.; Grant, B.; Deep-Sea Res. 1982, $29,1355$.

10. Edmond, J. M.; Palma, M. R.; Measures, C. I.; Grant, B.; Stallard, R. F.; Geochim. Cosmochim. Acta 1995, 59, 3301.

11. Berner, R.A.; Rao, J.L.; Geochim. Cosmochim. Acta 1994, $58,2333$.

12. Devol, A.H.; Foersbeg, B.R.; Richey, J.E.; Pimentel, T.P.; Global Biogeochem. Cycles 1995, 9, 307.

13. Fernandes, E. A.N; Ferraz, E.S.B; Oliveira, H.; J. Radion. Nucl. Chem. 1994, 179, 251.

14. Ferraz, E.S.B.; Fernandes, E.A.N.; Mar. Freshw. Res. 1995, 46, 107.

15. Konhauser, K.O.; Kyfe, W.S.; Kronberg, B.I.; Chem. Geol. 1994, 111, 155.

16. Meybech, M.; Amer. J. Sci.; 1987, 287, 401.

17. Williams, M.R.; Fisher, T.R.; Melack, J.M.; Biogeochem. 1997, $38,303$.

18. Benaim, J. Y.; Mounier, S.; Croat. Chem. Acta 1998, 71, 405.

19. Hacon, S.; Artaxo, P.; Gerab, F.; Yamasoe, M.A.; Campos, R.C.; Conti L.F.; Lacerda, L.D.; Water, Air, Soil Pollut. 1995, $80,273$.

20. Eisenreich, S. J. ; Hoffmann, M. R. ; Rastetter, D ; Yost, E.; Maier, W. J.; Proc. 175 ${ }^{\text {th }}$ Meeting of the Am. Chem. Soc., Anaheim, USA, 1980.
21. Nuernberg, H. W. In Complexation of Trace Metals in Natural Waters; Kramer, C.J.M.; Duinker, J.C., eds.; Martinus Nijohoff / Dr. W. Junk Publ.: The Hague, 1984, p. 95.

22. Zhou, X.; Wangersky, P.; Mar. Chem. 1989, 26, 21.

23. Plasivic, M. ; Krznaric, D.; Branica, M.; Mar. Chem. 1982, 11, 17.

24. van den Berg, C. M. G. In Complexation of Trace Metals in Natural Waters; Kramer, C. J. M.; Duinker, J. C., eds.; Martinus Nijohoff / Dr. W. Junk Publ.: The Hague, 1984, p. 17.

25. Ruzic, I.; Anal. Chim. Acta 1982, 140, 99.

26. Ruzic, I.; Mar. Chem. 1997, 53, 1.

27. Morel, F. M. M. In Principles of Aquatic Chemistry; John Wiley \& Sons: New York, 1983, p. 237-266.

28. Williams, M.R.; Fisher, T.R.; Melack, J.M.; Atmos. Environ. 1997, 31, 207.

29. Artaxo, P.; Gerab, F.; Yamasoe, M.A.; Martins, J.V.; J. Geophys. Res. 1994, 99, 22857.

30. Cassela, J.H.; M. Sci. Dissertation, Pontifícia Universidade Católica do Rio de Janeiro, Brazil, 1996.

31. Buffle, J. In Complexation Reactions in Aquatic Systems Analytical Approach; Ellis Horwood: London, 1990, p. 314322.

32. van den Berg, C.M.G.; Rebello, A. de L.; Sci. Total Environ. 1986, 38,37 . 